\title{
寛文12年再建の瑠璃寺本堂の造営文書と大工について ON BUILDINGG RECORDS AND CARPENTERS OF THE MAIN HALL OF RURI-JI TEMPLE, NAGANO, RECONSTRUCTED IN 1672
}

\author{
吉澤 政已 \\ Masami YOSHIZAWA
}

\begin{abstract}
In Ruri-ji temple (Takamori, Nagano prefecture) are kept a.number of archives including 28 building records of the main hall reconstructed in 1672. Inquiring into building specifications (so-called "Jiwari-tyumon") and quantity sheets of material (so-called "Kiyose") made conditions of building the main hall at that time clear, such as follows: on planning and construction, master carpenters submitted the specification and the quantity sheet of the main hall to the client (Ruri-ji) at first, and then the client gave an order for building materials. On carved members like "kaerumata" ware also ordered by the client.
\end{abstract}

Keywords: Shi yousaki,Ki yose,Ukeoi,Carpenter,Edo Period,Ruri-ji temple 仕様書、木寄、請負、大工、江户時代、瑠璃寺

\section{1.はじめに}

瑠璃寺は、長野県の南部、下伊那郡高森町にある天台 宗の古刹で、本堂は寛文12年(1672)に再建された三間堂 で、薬師堂ともよばれている1”。この本堂は昭和56年度 の「長野県近世社寺建築繁急調査」 2)で調查され、平面 形式（柱の立方方）として天台真言系三間堂の類型上 1 つの基本型を示していることが判明している ${ }^{3)}$ 。

瑠璃寺には多数の古文書が残されており、今回その資 料整理がおこなわれ「瑠璃寺古文書目録」がまとめられ た.?。この結果、本堂の造営に関する注文書(建築仕様 書)が 2 点、木寄(木材数量計算書)が 5 点、勧進帳が 2 点、奉加帳が15点など合わせて28点の本堂造営史料が確 認された。これまで長野県内にある17世紀中期の建築に ついて棟札以外のまとまった造営史料の残されている事 例はあまり知られていない5)。そこで本堂造営に係わる 史料についてその内容を検討し、当時の設計・施工の進 め方がどのような形態であったのか、造営に係わった大 工がどのような大工であったのか、また瑠璃寺本堂が当 時の信州のほかの建築と比較してどのような建筑的特徴 をもっているのかにっいて考察したい。

\section{2. 瀷䞍寺本堂の摡要}

本堂は、方三間、入母屋造、鉄板茸(元こけら茸)の堂 （図 1、3 )で、四方に縁をめぐらし、一間の向拝をつけ る。内部は四天柱のうち来迎柱を側柱筋より後退して立 て、平面は前一間通りを外陣、後ろ二間を内陣とする。 主屋の正面中央に両開きの格子戸(元は両折栈唐戸)を入 れ両側面中央は片引の舞良戸とし、ほかは横羽目板壁と する。ただし、外陣部分は、腰貫上に横連子空をつける。

構造は、側まわりは円柱を立て、縁長押・腰貫・内法 長押・飛貫・頭貫・台輪で固め、組物は出組とする。中 備は四面の中央を本幕股とし、ほかは撥束とする。妻穊 は虹梁大瓶束とし、篙形をつけ、軒は二軒の繁垂木とす る。天井は中央を鏡天井、周囲を化精屋根裹とする。

向洋は整盤の上に大面取角柱を立て、根肘木付の虹梁 でつなぎ、正面側に唐獅子、側面側に象の木鼻をつける。 中備に本蟇股をいれる。組物は血斗付大斗に出三斗をお き、さらに通时木を通し、連三斗・実肘木で析を受ける。 手挾は牡丹の籠彫とする。主屋とは根肘木付の海老虹梁 で慗ぐ。軒は打越垂木を用いた二軒繁垂木とする。

この本堂は元文 4 年(1739)に大風のため大破し、修理
信州大学工学部社会開発工学科 大学院生 工修
Graduate Student, Dept. of Architecture and Civil Engineering, Faculty of Engineering, Univ. of Shinshu, M. Eng. 
されている( ${ }^{6}$ 。本堂の軸部には取り替えられた部材がみ えないが、背面の垂木には反りがないので、背面側の屋 根が大破したものと考えられる。

\section{3. 造営史料}

本堂の造営に関係する史料は、万治 3 年(1660)の『信 州大嶋山本堂钓進帳』をはじめ28点あるが、ここでは建 築に直接関係する 7 点の史料を検討した。

\section{(1) 棟札}

「奉修造薬師堂一宇」の棟札には「大工 飯田之住 田辺 太右衛門尉為長」とあり、また、「信州伊那郡大鳴山瑠 璃寺本堂辛亥十月三日始翌年仲冬吉日成就畢」とあるの で、寛文11年10月に着工され、翌12年11月に竣工し、大 工は田辺太右衛門尉為長であったことがわかる。

(2) 寞文 3 年「御薬師堂木寄」・「御本堂御材木之覚」 寛文 3 年の木寄は 2 通あり、 1 通は 2 月に飯田善太郎 （大工、後述）が提出した「御薬師堂木寄」(図 2 )、も う 1 通は 3 月10日の日付がある「御本堂御材木之賞」で ある。

$$
\begin{aligned}
& \text { 飯田善太郎の署名のある木寄の内容は、 } \\
& \text { 「御薬師堂木寄 }
\end{aligned}
$$

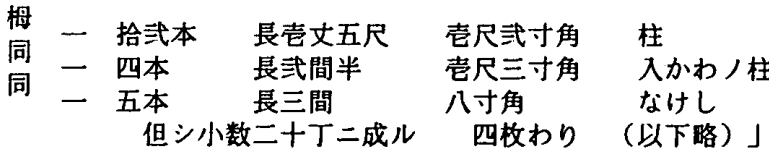

でもう 1 通の「御本堂御材木之覚」の内容は引物（土 居标）之軒桔木の松丸太が記されていない以外はまった く同様である。末尾に「右之代金式拾両二相定性御請申 候 (中略)、当年中二急度相渡し可申候(中略)、大嶋山法 印様、御内行善坊様」とあり、請主は高遠の桜木重兵衛、 請人は市田(現高森町)の上沼長四郎 (大工、後述)、新 井(現松川町)の城田善兵衛ほかの連名があり、請目証文 の形式をとっている。つまり、飯田善太郎の木寄にした がって寺が発注し、桜木重兵衛が材木納入を請け負った ことを示している。

\section{（3）寛文 6 年「注文之うつし}

ところが、この契約が成立した 3 カ月後に本堂再建を 発願した48世信応は遷化する。49世亮応は再建事業を継 続し材木納入の管理から始めたが、当初から材木納入が 滞っており、寛文 4 年10月には奉行所(飯田藩) に「乍 恐言上仕候事」として本堂建築材木納入が滞っているこ とを訴えている（寺文書）。

寛文 6 年 2 月の「注文之うつし」は、同 3 年に契約し た「御本堂御材木之覚」を納品検査のために書き写した もので、文末に「み大小数三百本、内百四拾式本大小 二而三度二うけ取分、残而百五拾八本いまた請取さる分」 とあり、この時点でもなかなか注文どおりの材木が納品 されていないことがわかる。

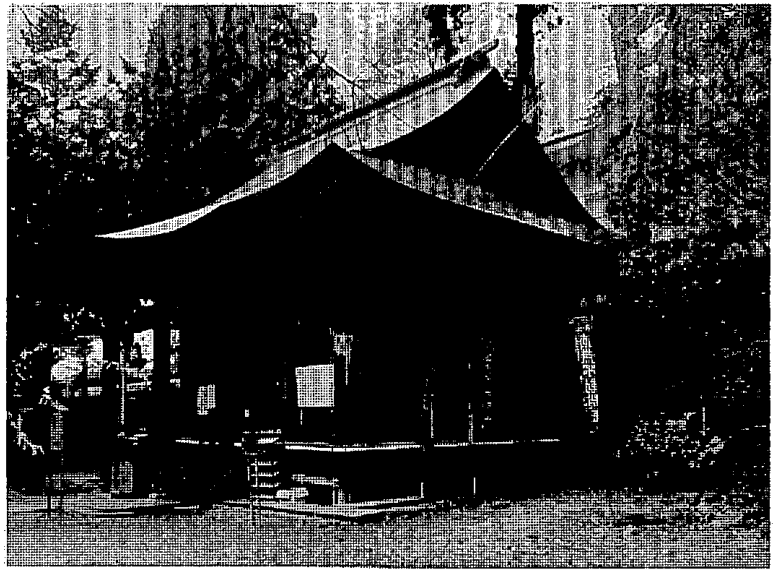

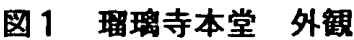

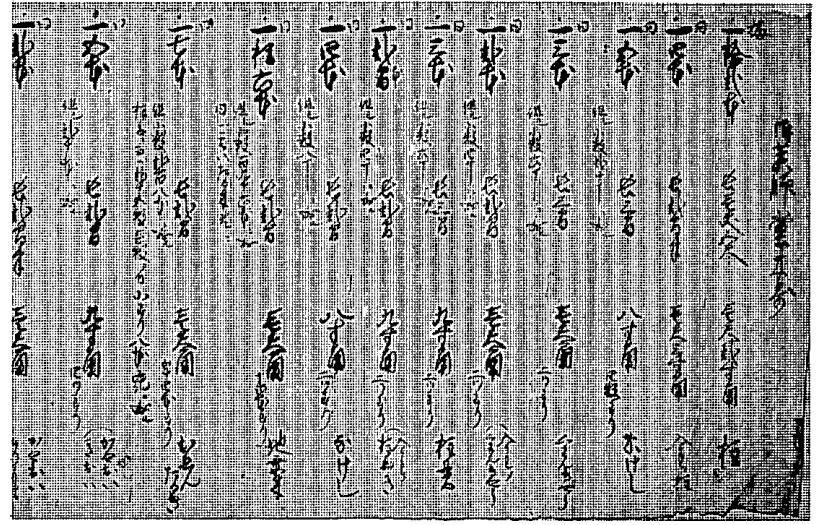

図2「御薬師堂木寄」(部分)

また、納品された材料も、

「相

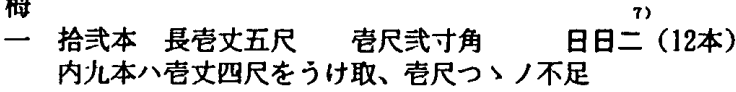

一四本長式間半壱尺三寸角 $\exists(4$ 本) 内武本八壱寸つ片不足 」

というように寸法通りとはいかなかった。「四本 長式 間半 壱尺三寸角」の柱は本堂の内部の柱を指しており、 現本堂の該当する柱を実測すると、来迎柱と手前 2 本の 柱では太さが異なっていた（図３）。文書には「内式本 八壱寸づつの不足」とあるから、木寄の寸法どおりに納 品された材を来迎柱にあて、太さが 1 寸不足して納品さ れた材を内陣・外陣境側の柱にあてたと確認できる。

このような状態であったので、同年 4 月には瑠璃寺か ら奉行所に再び「乍恐御訴訟申上仕候事」として本堂建 築木材の納入滞りを訴えている (寺文書)。

\section{（4）「大間三間四面ノ堂ノ木寄ノ注文」}

次に、寛文 8 年と裏書き ${ }^{8)}$ のある「大間三間四面ノ堂 ノ木寄ノ注文」をみると、木寄の内容は「御薬師堂木寄」 や「注文之うつし」と拾い方に違いがみられる(表 1)。

柱についてみると、「御薬師堂木寄」と「注文之うつ し」では側柱(1尺2寸角)が12本、入側/柱(1尺3寸角) が 4 本、向拝柱(1尺角) が 2 本の合計18本の柱を数え、 「大間三間四面ノ堂ノ木寄ノ注文」ではすべて1尺1捔 
表 1 寛文 3 年と同 8 年の木寄比較.

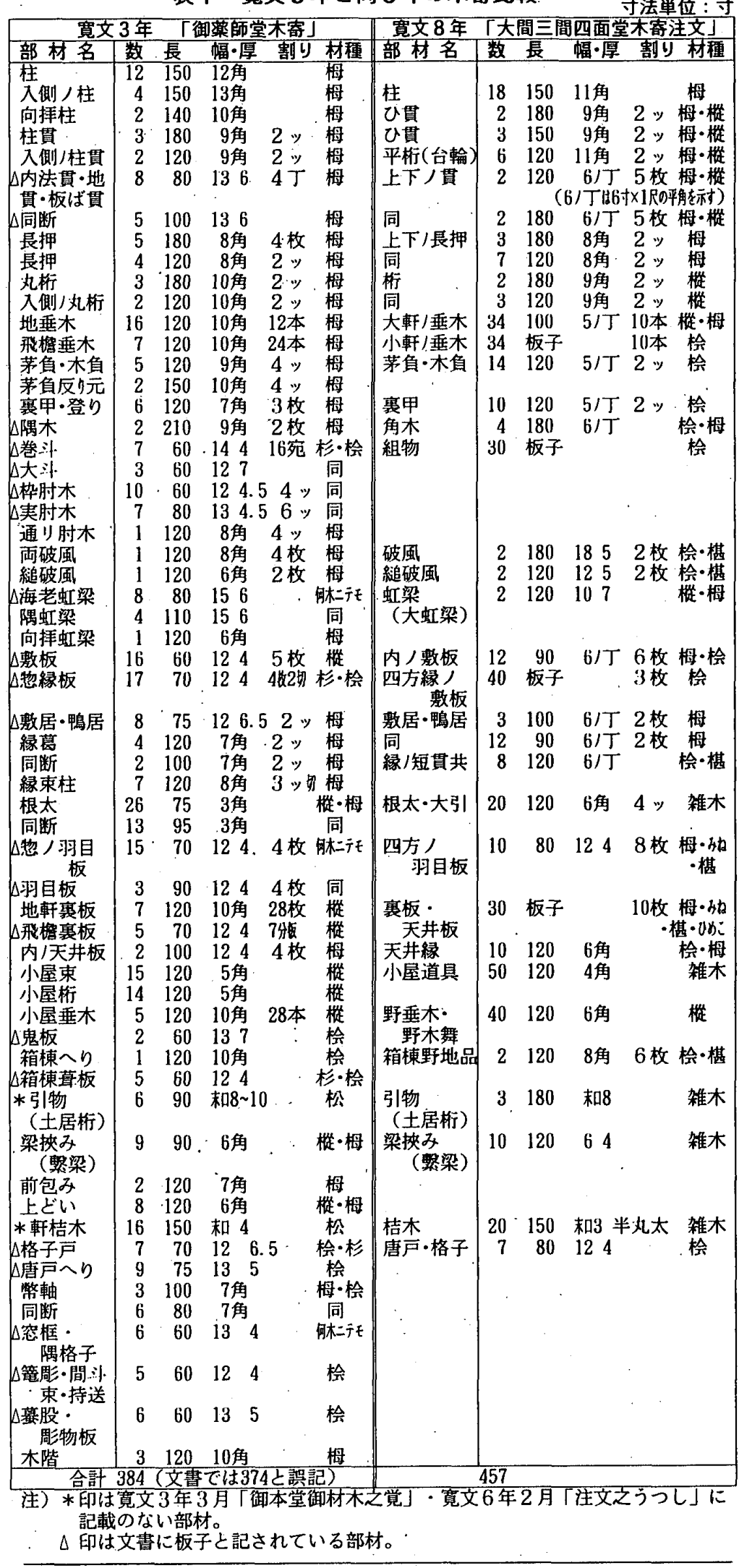

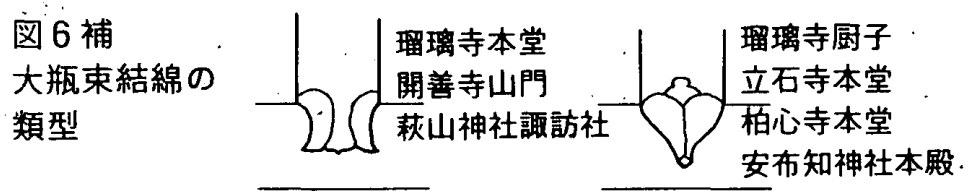

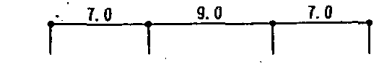

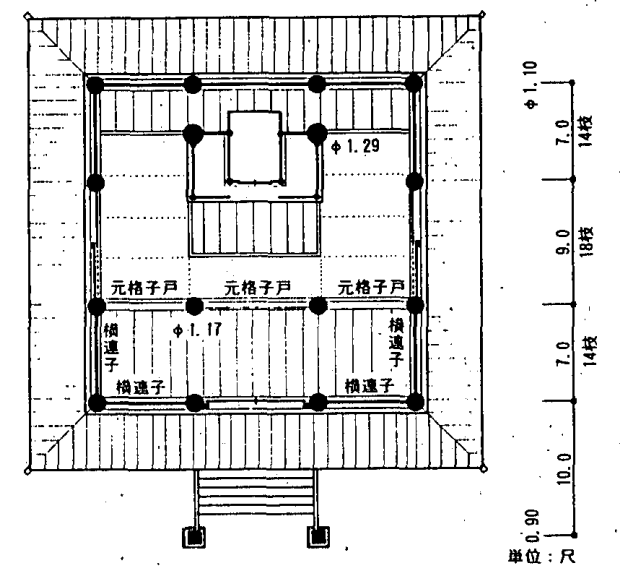

图3㯰㷎寺本堂 平面図

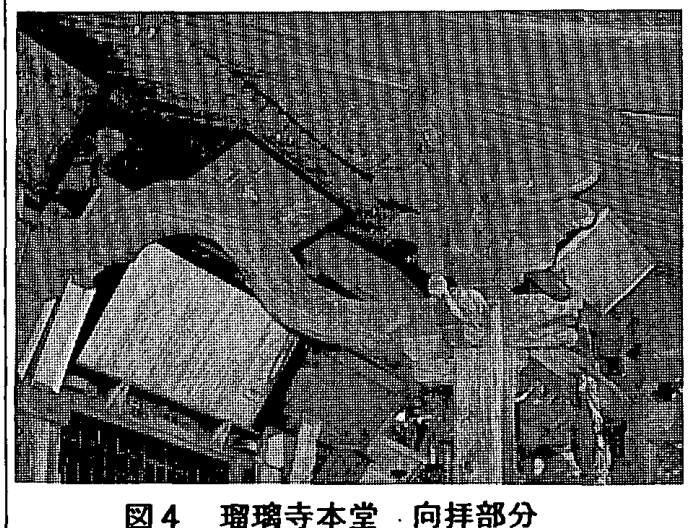

図 4 瑠璃寺本堂．向拝部分
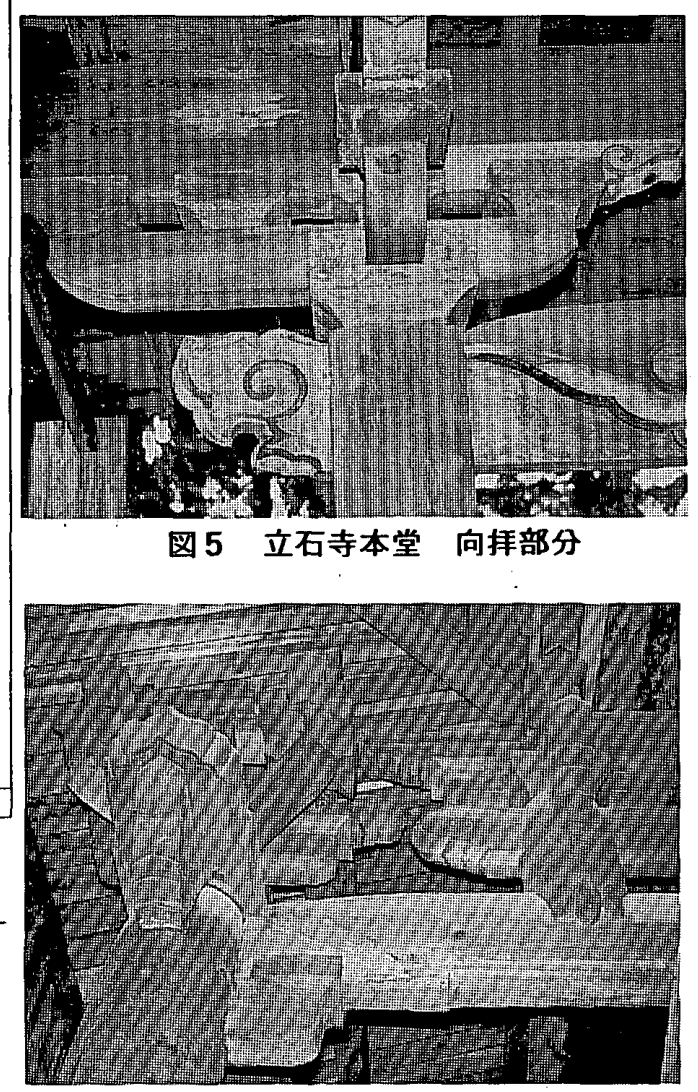

図 6 琾噙寺本堂 来讯柱上部の架搆 
表 2 注文書と現在の本堂との此較

\begin{tabular}{|c|c|c|c|}
\hline & A：大鳴山察師堂作事之注文 & B：本堂作始之注文 & 現本堂 \\
\hline 平面規模 & 大間 9尺脇間 7尺三間四面 & 同左 & 同左 \\
\hline & 丸柱 & 同左 & 左 \\
\hline $\begin{array}{l}\text { 組物 } \\
\text { 中借 }\end{array}$ & 三斗 & 出組·拳鼻付、支輪 & 同左、支輪なし \\
\hline & & 㓣間斗涑 & $\begin{array}{l}\text { 同厓 } \\
\text { 同左 }\end{array}$ \\
\hline 頭貫 & 木鼾は非鼻 & 木鼻付、台輪 & 同左 \\
\hline 軸部 & 上下 & 同左 & \\
\hline 空 & 敕軸付 & 同左 & 横連子(幣 \\
\hline 建具 & j折栈唐戸 & 同左 & 巨現在 \\
\hline & F各 1 本 & 同左 & 同左 \\
\hline 板壁 & 横羽自 & 同左 & 原（合决り \\
\hline 繣 & 四方切 & 同左 & \\
\hline 俥 & 二軒垂木半繁もの & 二軒㢣もの & E(熬垂木) \\
\hline 屋根 & 両妻入母屋そなえ & 同左 & 同左(入母屋造) \\
\hline 妻飾 & 虹梁・大瓶束 & 虹梁・大瓶束 & 同左、笼形 \\
\hline 魹魚 & おおい鯺 & $\begin{array}{l}\text { 三ッ花㫥魚、鲔籠彫 } \\
\text { 同左 }\end{array}$ & 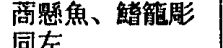 \\
\hline 内部天井 & 周囲は化粧屋根襄 & 同左 & 同左 \\
\hline & & 同左 & 同左 \\
\hline 内部架構 & 外側柱から内部柱に虹梁・ & 同左 & 同左 \\
\hline 内陣·外 & 格子户 & 同左 & 同左(現在 \\
\hline 陣境 & 欄 & 大間彫物、脇花狭間 & 全て菱格子 \\
\hline 来迎柱 & 頭貫、台輪、組物は三斗 4 具 & 同左 & 同右 \\
\hline 須弥壇 & 胗刻、高欄は逆蓮華 & 同 & 同 \\
\hline 内陣両䐦 & 箱仏壇、高欄は平高欄 & 同左 & 同左 \\
\hline & 内陣·外陣と & 同左 & \\
\hline 向择柱 & 礎艋付 & 几撗面取、礎盤付 & 大面取、礎盤付 \\
\hline 木鼻 & & 象粤、獅子鼻(足付) & 同左(足なし) \\
\hline 組 & 三市. & & \\
\hline 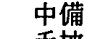 & 㱳股 & 外注） & \\
\hline 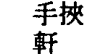 & & 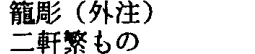 & $\begin{array}{l}\text { 同左 } \\
\text { 同左 (打越垂木) }\end{array}$ \\
\hline
\end{tabular}

の柱で18本を数えている。一方、韭木数は剖者で は地垂木を196本(長さ12尺)、飛桅垂木を208本 （長さ12尺)に計算し、後者では地垂木(長さ10尺)、 飛檐垂木(長さ6尺程) ともに340本として、大きく 異なる。これは、前者では半繁垂木で拾い、後者 では繁垂木で拾っていることを示している。9

柱上部の部材についてみると、前者では頭貫の みを木奇し、後者では頭貫と平桁(台輸)を木寄し ている。この点では後者の木寄が現本堂と一致し ている。しかし、後者の木寄では柱太さはすべて1 尺1寸であるが、現本堂の内部柱の太さは前述のよ うに寛文 6 年の材木検査の結果(「注文之うつし」) と一致している。つまり現本堂は、柱太さでは 「注文之うっし」と一致するものの、部材の木奇 では「大間三間四面ノ堂ノ木寄ノ注文」と一致す る。このように、現本堂には双方の文書の内容を 混合した結果があらわれている。

また、木寄の内容は本堂全体の部材に及んでお り、棟札には「奉修造」と記されているが、史料 や遺構を見る限り寛文 12 年の工事の内容は修理で はなく再建 (新築) であったことがわかる。

（5）「大饱山薬師堂作事之注文」亡「本堂作始 之注文」

表 3 「大沜山薬師堂作事之注文」の内容

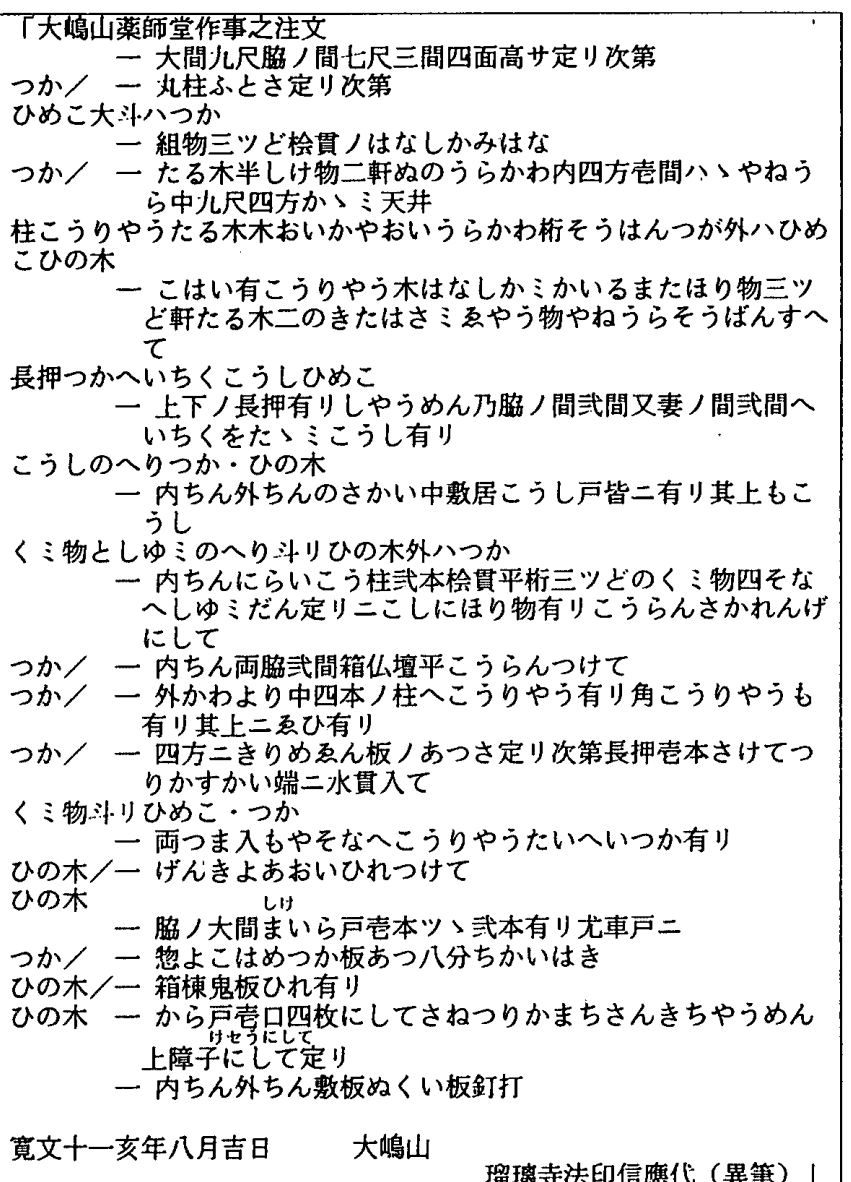
(/印は原文で改行されているものを追い込みした記号)
寛文11年の「大嶋山薬師堂作事之注文」（以下文書 $\mathrm{A}$ と称す）と年号不詳の「本堂作始之注文」（同 文書 B ） はいずれも本堂の仕様を記したものである(表 $2 、 3$ )。 文書 B は一度清書された行間に異筆で細部について追加 事項が記されている。

これら 2 通の注文書(文書 A・B )は筆跡や記載の順番 は同一ではないが、内容として共通しているのは、「大 間儿尺脇ノ間七尺三間四面高サ定り次第」、「軒二軒内四 方壱間づつ屋根裏中儿尺四方鏡天井」などて、現本堂の 構造形式の内容を示している。仕様で異なっているのは、 1つには向拝の木鼻の仕様で、文書 Aでは「向拝あり、 虹梁木鼻しかミ慕股彫り物、三斗、軒垂木二軒、手㣣み 絵様物」とあり、文書 Bでは「向拝虹梁の木鼻象鼻、手 挾籠彫り届次第、その木鼻獅子嶴足付き二」とある点で ある。もう1つは主屋の軒の形式で、文書Aでは「垂木 半しげ物」(半繁垂木)とし、文書Bでは「二軒しげ物」(繁 垂木)としている点である。これらの内容が現在の本堂 と一致するのは文書 B の仕様である。

つぎに、垂木と側柱上部の仕様に着目し、注文書の内 容と前述の寛文 3 年の木奇とを比較すると、半繁垂木で 頭貫だけを用いる文書 A の内容が飯田善太郎の署名のあ る「御薬師堂木奇」の内容と一致し、繁垂木で頭貫と台 輪を用いる文書 B の内容は「大間三間四面ノ堂ノ木奇ノ 注文」や現本堂の仕様と一致している。

文書 Bで注目されるのは、一度清書された行間に異筆 
で追加事項が記され、さらに末尼に「右地わり注文之通 リノ本堂之地かり $习$ 寸かぞへ二被成御見七可給候」とあ る点である。これは、文書 Bが大工から示された設計仕 様を書き写し、さらに追加事項を記入し、再度大工に注 文した下書きであることを示しており、また、劸ら大 エにこの地割注文による縮尺 $1 / 10$ の図面（建地割）の 提出を要求した内容となっている。つまり、棟梁がまず 様式を箇条書きした建築仕様書を施主に示し、施主がこ 扎に追加事項を記入し、こうしてまとまった内容にした がって棟梁が図面を作成するという設計段階の進め方を 示している。また、上述のように注文書の内容と木奇の 内容が一致するということは、棟梁がまず仕様書を作成 し、これにしたがって木奇もおこない、これら一対の書 類を施主に提出したものと考えられる。

\section{4. 販田善太郎と彼の意匠の特色について}

飯田善太郎は万治年間ころに和泉国堺から駒場村(現 阿智村)に移住した大工でるる

この飯田善太郎は、寛文 6 年に満光寺本堂（焼失、高 遠町）を建てた「大工棟梁、本国泉州堺住人、当国駒場 住飯田善太郎重光」（満光寺文書）と同一人物と考元ら れる。被の作品としては、立石寺本堂（寛文 9 年、飯田 市)、柏心寺本堂（寞文10年頃、飯田市）"'がある。

善太郎が立石寺本堂を造営したことは、棟札に寞文 7 年 2 月に細工始をし、同 9 年 8 月に入仙供養をしたこと、 大工が飯田善太郎と山本金右衛門であったことが記され ていることからわかる。この本堂は間口の柱間を 7 尺・ 9 尺・7尺の三間にとる入母屋造の建築（一間向拝付） で、間口の柱間寸法は瑠璃寺本堂と同一である。軒や向 拝の形式をみると、軒は二軒の半繁垂木で、向择には虹 梁形頭貫に繁のついた木鼻をつけ連三斗を組んでいる （図 5 )。この仕様は前述の「大嶋山薬師堂作事之注文」 にある「半しげ物」、「虹梁木鼻しかミ慕股彫り物」に 相当する。また、側まわりの柱上部は頭貫(木鼻は㢣付） を通し、三头(拳鼻付)を組み、台輪を用いていない。こ れも「組物三ッ斗桧貫ノ鼻しかみ鼻」と一致している。

立石寺本堂にみられる善太郎の意匠の特色は、半繁垂 木で頭貫だけを用いる「大嶋山薬師堂作事之注文」の内 容と共通点が多く、また前述のように「大嶋山薬師堂作 事之注文」は善太郎の署名のある「御薬師堂木寄」の内 容と一致しているから、「大嶋山薬師堂作事之注文」は、 寛文 3 年に善太郎が瑠璃寺に提出した「御薬師堂木奇」 と一対の仕様書の内容とみることができる。

つまり、寛文 3 年に彼が瑠璃寺に提出した「御薬師堂 木寄」と一対の仕梯書があり、これを寺で寛文11年に書 き写したものが「大嶋山薬師堂作事之注文」であると考 えられる。おそらく「本堂作始之注文」の参考にするた
めに書き写したのであろう。寛文 3 年に彼が罳璃寺に仕 様書と木奇を提出したと判断できるので、その洔点では 瑠瑙寺本堂の造営は飯田善太郎が棟梁として着工される 手筈であったと考えられる。

寛文 3 年に瑠璃寺に「御薬師堂木寄」を提出して以後 の彼の造営記録をみると、満光寺本堂（同6 年完成）は 同 4 年ころには造営に着手していたと考えられ(2)、前 述のように瑠璃寺はこの時点では建築用材の大半が未納 入の状態であったから、おそらく早く材木の集まった淽 光寺本堂の建設に彼は着手したもの之みられる。満光寺 本堂が完成した寛文 6 年でも瑠唡寺では材木納入は依然 半分程度の状況であった。善太郎は翌 7 年 2 月に立石寺 本堂の造営に着手し、同 9 年 8 月に立石寺本堂を完成さ せ、同10年ころには柏心寺本堂を完成させていることか ら、立石寺本堂の造営の後半からは柏心寺本堂の造営も 重複して着手されていたものと考えられる。

つまり、寛文 3 年の時点では善太郎は瑠璃寺本堂の造 営も可能な状況であったが、その後は彼の動向をみる限 り瑠愣寺本堂以外の造営で手一杯となっている。こうし た状況の中で寛文 8 年の「大間三間四面ノ堂ノ木寄ノ注 文」が登場したのであろう。つまり、本堂造営棟梁の交 替がこの頃にあったと考えられ、また、「大間三間四面 ノ堂ノ木寄ノ注文」に記された根拠の明らかでない寛文 8 年の年紀も妥当な年紀とみなされる。

\section{5. 田辺太右衛門尉為長について}

田辺太右衛門の名前は瑠璃寺本堂が今のところ初出で、 その後、貞享 3 年(1686)の吉田神社の棟札 '3)、同 5 年の 白山社奥社本殿(飯田市、重要文化財)の修理棟札 ${ }^{11)}$ にそ の名前がみられる。つまり太右衛門は瑠璃寺本堂建立の 頃から飯田の大工として頭角をあらわしたことになる。

ところで、瑠璃寺本堂の大瓶束の結綿（図6）は天文 18年(1549)ころの建立 ${ }^{15)}$ 之推定される開善寺山門(飯田 市、重要文化財)や承応 2 年(1653)建立 ${ }^{16)}$ の萩山神社諏 訪社(高森町)の大瓶束結綿とよく似ている。この大瓶束 結綿の類似性と大工の関係をみてみたい。

開善寺山門は慶長 5 年(1600)以前に開善寺番匠清水筑 後（慶長 5 年没)によって修理されている の清水氏の名前は元和 7 年(1621)の桐林八幡宮(飯田市) の棟札 ${ }^{18)}$ に清水四郎右衛門があり、寛永 8 年(1631)の

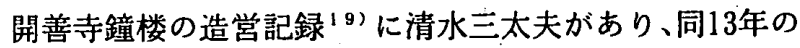
上川路八幡宮の造営記録 ${ }^{20}$ ) に清水伝右衛門為有(筑後の $\left.子^{211}\right)$ 、同19年の伊豆木八幡宮の木桘銘 ${ }^{21}$ に清水伝一 郎とあり、承応 2 年の萩山神社諏訪社の束墨書 ${ }^{23)}$ に清 水伝右衛門為定丞とある。つまり清水氏は17世紀前半に 開善寺を拠点として周辺の造営に登場する大工である。 この清水氏が「為有」「為定」を名のっており、田辺太 
右衛門が「為長」を名のっているので、田辽氏は清水氏 の後継者という位置づけが考えられる。また、萩山神社 諏訪社の束量書には清水伝右衛門のほかに市田村の上沼 長四郎清網の名前があり、この上沼長四郎は前述の「御 本堂御材木之覚」に請人として連名している「市田村上 沼長四郎」と同一人物と考えられる。萩山神社諏訪社と 瑠璃寺本堂の双方に上沼長四郎の名前が出てくることと 瑠璃寺本堂の大瓶束結綿が開善寺山門や萩山神社諏訪社 の大瓶束結綿とよく似ていることとは無縁ではなく、技 法の類似性は清水・上沼・田辺氏という大工のつながり があって生じたと考えられる。また、飯田善太郎が立石 寺本堂に足掛け 3 年を要しているのに、田辺太右衛門が 同規模の瑠璃寺本堂を 1 年余で仕上げているのも、清水 上沼氏による組織力が背景にあると考えられる24)。

これらから、瑠璃寺本堂の造営は、和泉国堺という技 術水準の高い地から飯田に移住した飯田善太郎が当初に 設計し、寛文 8 年頃に開善寺番匠として活動していた清 水氏系列の田辺太右衛門に変更されたと考えられる。田 辺氏の名前はこの時期の飯田周辺の建築に限られている ので、田辺氏もまた飯田善太郎のように畿内から移住し てきた大工ではないかと推定される。

\section{6. 琾璃寺本堂造営ころの建築遗構と技法}

下伊那地方の 17 世紀中期の建築遗構のうち向拝をもつ 建築について、向拝の木鼻、組物、中備、主屋との繫き、 手挾の有無を比較すると次のようになる。

\begin{tabular}{|c|c|c|c|c|c|c|}
\hline 年代 & 建 & 大鼻 & 肳 & 中備 & \&き & \\
\hline 2 & 如神社諏訪社 & 象 & 連二 & 暴股 & 海老虹: & \\
\hline 伩 2 年 & 泊ヶ嶺八幡宮本殿（㽖南） & ) 象 & 連三: & 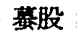 & 海老虹梁 & \\
\hline 兄 & 立 & & 連三 & 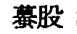 & 海- & \\
\hline 寛文11年 & 安布知 & 绿 & 連三斗 & 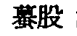 & 䀲若 & \\
\hline 2年 & 瑠璃寺 & 象·睤 & 三斗 2 传 & " & 海老 & \\
\hline 延宝 6 年 & 挏林八 & & 連三斗 & 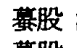 & II 梁 & \\
\hline
\end{tabular}

これからみると向拝の木鼻に象と唐獅子を付け、手挾 (籠彫)をつけた建築はこの時期の下伊那地方では瑠璃寺 本堂だけである。県内のこの時期の建築で象と唐獅子な ど丸彫の木鼻を向洋柱上部の前方と頭貫方向の 2 面に付 け、籠彫の手挫をつけている建築は、

万治 3 年 真田信之篮屋 (長野市、重要文化財)

宽文 5 年 真楽寺観音堂 (御代田町)

など数少ない。つまり、田辺氏の仕様は信濃では後の 18 世紀前半から用いられるようになる様式を先取りしてい ることになる。ただし籠彫の手挫、蟇股は、「たばさミか ごり届次第小「四方/大間二かいるまたこはいとも五ッ かごほり届次第」(「本堂作始之注文」)とあり、これは輸 送可能な手挾や慕股などの籠彫を寺が外注したことを示 していると考えられる。江戸中期に絵様や彫刻を施した 部材を遠方まで輸送した実態については、永井規男氏の
「近世大坂大工宮屋とその営業形態」25)で明らかにされ ており、また、当初に瑠璃寺本堂の設計をした善太郎の 生国和泉国塌には寞文期以前から彫物師がいたことが、 大河直躬氏の「幕府の建築と作事方 $\rfloor^{26)}$ や谷直樹氏の

「寛永期における中井家配下の大工構成」27)で明らかに されており、おそらく寺も田辺氏を通じてこうした彫物 師に依頼したのであろう。とすれば信濃のこの時期の建 筑として先進的な要素があることも理解できる。

\section{7. まとめ}

造営史料の検討から、瑠璃寺本堂の建設過程は次のよ うに整理されよう。

万治 3 年に瑠璃寺 48 世信応によって発願された本堂の 再建は、寛文 3 年 2 月に飯田善太郎の設計、木寄によ。 て具体的な内容が固められたと考えられ、翌 3 月には材 木納入の請負契約もおこなわれた。しかし、この年の 6 月に信応が菤化し、これを継承した49世亮応の時代の初 期には材木の納入は契約どおりに履行されておらず、寛 文 6 年になっても全体の半数が納入されただけという状 況で、寺では奉行所にも訴え出た。その後、寛文 8 年頃 に飯田善太郎が棟梁を降り、当時飯田で勢力をもってい た清水氏系列に属していたとみられる田辺太右衛門が棟 梁となった。彼は自分の仕様書、木寄を提出したが、既 に集まっている部材については寸法等を変更した。そし て本堂再建は寛文11年10月にようやく着工にこぎつけ、 翌12年11月に完成したのである。

工事の進め方については、まず、施主が棟梁を選択し、 指名された棟梁は建築の内容を詳細に箇条書きした仕様 書の作成と木寄をおこない、この木寄をもとに施主が材 木を発注するという形態であったことが明らかとなった。 また、瑠璃寺の場合は、この後に棟梁に対して建地割を 要求している。これは設計図面を施主に提示することが ある程度普及していたことを示していると考えられる。

このように造営に着手する以前の状涗については、史 料や周辺の瓷料から明らかとなったが、着工から竣工ま での状況については史料を欠き、大工手間が請目 ${ }^{28)}$ あったのか直用であったのかという点などは明らかでは ない。瑠璃寺本堂の場合、大工手間が請目契約であれば、 仕様書の末尼に「御本堂御材木之覚」と同様に、請負金 額、支払い方法、工期などが記されたであろうし、また、 18世紀後期のように立面図や木寄注文を最初に提示し、 その後に仕様・請負金額・工期などを列記した請目証文 が交されるという手順 ${ }^{29}$ であれば、当初に棟梁であっ た飯田善太郎が途中で田辺太右衛門に交替するというよ うなことは通常では起こりがたいことである。しかし、 前述のように棟梁の交替は現実におこなわれ、この交替 の時期に善太郎は立石寺本堂を造営しており、彼が契約 
に拘束されて活動していたとは考えられない。つまり、 瑠璃寺本堂の造営では大工職人については寺が直用して 日当を支払う方法であったと推定され、したがって着工 以前に棟梁の交替があっても、大工に契約不履行という 不名誉な結果が生じることはなかったものと考える。

次に、瑠璃寺本堂の様式や技法についてみると、来迎 柱が残っている点では室町時代の伝統が残されているが、 向洋木鼻や手摤・蟇股などの籠彫は信濃では18世紀前半 から用いられるようになる技法を先取りしている。つま り、伝統的な部分と当時の信濃の建築としては最先端に 属する技法が混在している点に瑠璃寺本堂の特色がある と考えられる。ただ、こうした籠彫の手挾・蟇股は外注 によって賄われたことが判明したので、地方における建 築様式の時代的な変遷は大工の移動や部材の外注の有無 を考虑することが必要であろう。

瑠璃寺本堂は、単に江戸時代中期初頭の建築として貴 重なだけでなく、設計仕様書や木材数量計算書という史 料が残され、遺構と史料が比較検討できる点で貴重であ る。さらに、その史料は寛文年間における設計の進め方、 契約の仕方、あるいは飯田周辺の大工勢力の背景を含ん だ内容をもっており、当時の信州南部の造営事情を知る 上でも貴重であることがわかった。

注

1) 慶長13年(1608)の「信州伊那郡大嶋山瑠琌教寺之縁起」によ れば、瑠傰寺は天永 3 年(1112)に比教山竹林院の観举僧都に よって大島川上流の「堂所」地籍に創建され、境内は最終的に は寛永元年(1624)に現在地に移っている。本尊の木造薬師如 来及両脚侍像(平安時代末期)は重要文化財。万治 3 年 $(1660)$ の「信州大嶋山本堂権進帳」には、「特二請蒙十方檀那助成 再興一宇伽藍勧進之状」として、寺の由来が薬師瑠璃光如来 にあること、さらにこの如来の功徳を記しており、瑠璃寺の 本堂は薬師如来をまつる薬師堂であることを示している。

2) 調查結果は、『長野県の近世社寺建築」（長野県教育委員会、 昭和57年）にまとめられている。

3）『近世社寺建筑の研究第 1 号一第 1 回近世社寺建築研究集会 記録』（奈良国立文化財研究所、昭和63年）による。

4) 平成 4 年に飯田市美術博物館が実施した。

5 ）室町時代のものでは享禄 4 年(1531)の善光寺造営図（建地割、 重要文化財）がある。江戸中期のものでは小泉家資料（地割· 木寄、寛文～元禄期、『佐久市志」美術建筑編、1995)、宝永 4 年(1707)の善光寺本堂(国宝)造営資料(建地割、長野県史」 美術建築凅料編 (2)建筑、1990)、宝永 8 年の若一王子神社三 重塔造営資料（建地割・木割、同）などがある。

6) 元文 4 年「本堂修復入用党」(瑠琌寺文書)

7 ) 納品の数を検查するのに「正」(5 画)の筆順にしたがって 5 本までを記すのではなく、「日」の文字を用い、ー・ニ・ 三・ヨ・日としている。

8）鈆筆書きされたもので、包み紙などに記されていた年号を近 代以降の史料整理のときに記したものと推定される。また、 「寞文十一亥年ノ前後、本堂建立之口板蚾作事注文書、 七通有之口通圆物蛙、法口、寛政六年口月晦日」と記された 虫食い状態の包み紙もあり、近世にも一度造営文書の整理が おこなわれている。

9） $196 \cdot 208$ 本は、木奇に「但シ小数百儿十六本二成儿、同ごは いたる木共二」と記された数字である。1 尺角を12本割とす ると垂木は削り代を考慮しない場合、幅2.5寸、背約 3.3 寸寸と なる。7尺・9尺・7尺の柱間をこの垂木で、半繁垂木（1枝7.5 寸) に枝割りすると、10枝・12枝・10枝または9枝・12枝・9枝に調整 される。これに柱筋外側の配付垂木を 6 枝(ま大津7枝)とり、向拝
に打越垂木を用い、向拝の螋羽を4枝とすると、 $(6+10+12+10+$ 6) $\times 4+12+4 \times 2=196$ となる。これに論台垂木を 1 凮3本宛てると 196+3×4=208の計算となる。木寄では、地垂木 1 尺角12本割 を16本(辰さ12尺)としてあり、計算上は、12×16=192よなる。 必要な垂木196本のうち、配付垂木は長さが12尺はいらない ので、小さめに本数を拾い上げている。

一方、寛文 8 年の木寄では、垂木は5 寸 $\times 1$ 尺の平角材を 10 本割としており、この垂木寸法は2.5寸×2寸となり、本繁垂 木(木間返し)の1枝は 4 寸となる。上述の柱間では、 $(10+17+22$ $+17+10) \times 4+22+6 \times 2=338($ 約 340 )の糟算と考えられる。

10）「阿智村誌」下巻(同誌利行委員会、昭和59年)、751 752面。同 䚾には飯田善太郎について、净土宗伊那谷寺院の触頭であっ た净久寺に万治 4 年に名号碑を奉納したこと、三門の閣魔坐 像の銘文（寛文 3 年）に「(前略) 炭予生国泉州堺住居謰以三 界六道有為転変世界四相僄流致也、(中略) 願主 信州伊那郡 伊柄庄駒場住居 藤原飯田善太郎重直、同内方 (以下略)」とあ ること、また、「中関村御年貢帳」(筧文12年)に駒場村からの入 作として「大工善太郎、8侥1斗5升5合5次才」とあることが記 されている。また、現段陼では、本稿に記した以外は大工飯 田氏に関する資料はなく、没年等も不明である。

11）立石寺本堂(観音堂)、柏心寺本堂は、「長野県の近世社寺建筑 一第二次調查報告書」(注22)に収録されている。柏心寺本堂 か殷田善太郎の作品と直接記された史料はないが、柏心寺本 堂の外陣にみられる海老虹梁・大瓶束・肘木(和様曲線をもつ) などの形は立石寺本堂の形式と同一で、善太郎の手によるも のと判断した。彼が仏像を奉納した净久寺、彼が再建した渵 光寺、そして筆者が彼の造営と判断した柏心寺はいずれも净 土宗の寺院という点で共通している。なお、柏心寺の建筮年 代は、内陣の華棈銘「寛文十庚戌年」から判断した。

12）立石寺本堂の造営が寛文 7 年 2 月から同 9 年 8 月まで足挂け 3 年かかっていることから判断した。

13）【高森町史」下巻（高森町史刊行会、昭和50年）、1107頁

14）「国宝白山社奥社本殿修理工事報告毒』（同修理事務所、昭 和15年）所収。「太右衛門」とあり、田辺氏と推定した。

15）【長野県史」美術建築資料編 (2)建榮（(社)長野県史刊行会、 1990）。開善寺は臨済宗の寺院。

16）前揭注 $2 、$ 注 13 。

17）「重要文化財開善寺山門修理工事報告書」（同修理委貝会編、 昭和36年）。墨毒および過去帳による。

18）【竜丘村誌」（竜丘村誌編集委員会、昭和43年）、677頁。

19）【下伊那史」第 5 巻（下伊那教育会、昭和42年）、610面。

20）【竜丘村詰」（前揭注18）、672頁。

21）過去帳による。前揭注17所収。

22）「長野県の近世社寺建築一第二次調查報告書』（長野県教育 委貝会、平成 3 年) 所収。

23）前揭注 $2 、$ 注 13 。

24）現段階では、田辺氏と清水氏がチームを組んで造営した資料 や、清水氏・上沼氏か㑭璃寺本堂の造営チームに加わってい たことを示す資料は見出されていない。ここでは、古い伝統 的な様式が継承されている根拠の可能性を提示した。

25）永井規男：「近世大坂大工宮屋とその営業形態」、日本建筑 学会論文報告集第390号、1988、108 116頁。

26）大河直躬：「幕府の建筑と作事方」(「世界建筑全集3」日本亚 近世、平凡社、1959、所収)。慶長11年(1606)の香取神宮造営資 料に、彫物名人で堺出身の可兵衛のことが記されている。

27）谷直樹：「寛永期における中井家配下の大工構成」、日本建 筑学会論文報告集第415号、1990、101 109頁。和泉国堺の 大エとして「和泉彫物与一郎」が記されている。

28）中世の請目の発生については、大河直躬氏の著書「番匠」(法 政大学出版局、1971、169 174頁)で考察されており、設計図に ついても同書(212 217頁)で考察されている。大河氏は「中世 後期に建築工事のなかで請目行為が芽ばえていたことは認め られるが、それは単純な内容の工事が多く、ひろく一般の工事 にひろがるには至らなか一た」とする。また、永井規男氏は、

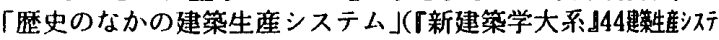
厶、彰国社、1982)の中で、手間請目は中世末期の段階でも、「工 事規模が小さいものに限ら扎ていた」(79頁)としている。

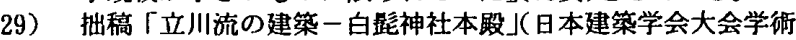
講演集、1984、2667 2668頁)、「立川流の建筑一矢彦神社择殿 殉郎」(同、1986、F 633 634頁) 参照。

（1995年 1 月 10 日原稿受理，1995年 4 月 24 日採用決定） 